Article

\title{
The Affirmation of Nothingness in Zhuang Zi's Humor
}

\section{Anton Heinrich L. Rennesland}

\begin{abstract}
I present an affirmation of nothingness in the humor of Zhuang Zi 莊子. This essay begins with two images that present a playful transgression of perspectives: the butterfly dream and the discussion over the Hao river. I dwell on these transgressions to highlight the challenge for each to question one's perspectives and to shift its grounding from epistemic to aesthetic value. Such a sensitivity suggests a mindfulness of the transformation of things 物化. This reinforces reality's ephemerality, and I, following David Chai, point what lies behind this as the non-being of nothingness 無無. The centrality of the Dao 道 qua nothingness is mirrored by a Daoist who becomes sensitive to the transformation of things and who ultimately undercomes reality, i.e., decenters oneself. This type of existence is what it means to be zhenuinly 真 pretending, which Zhuang Zi does, manifested by the humor in his work.
\end{abstract}

Keywords: Zhuang Zi 莊子, transformation of things 物化, non-being of nothingness 無無, genuineness 真

$\mathrm{I}$ n his book, Zhuangzi and the Becoming of Nothingness, David Chai expresses that one of the challenges of Daoism to the western mind is the possibility Lof "overcoming the impossibility of knowing what is directly unknowable." ${ }^{1}$ Doing this requires a mindfulness of how reality ultimately surpasses the self, or perhaps as an attempt to be released from this logic, a mindlessness of reality. This use of mindlessness suggests loosening the tie between the mind and reality, i.e., the imposition of oppositional pairs such as being-non-being, cause-effect, and others on reality. This type of mindlessness is vital since the Oriental way of thinking posits a consciousness grounded not on identity or opposition but on the harmony of such apparent

${ }^{1}$ David Chai, Zhuangzi and The Becoming of Nothingness (Albany: State University of New York Press, 2019), 1.

(C) 2021 Anton Heinrich L. Rennesland

https://www.kritike.org/journal/issue 28/rennesland1 june2021.pdf

ISSN 1908-7330

$(c c))$ BY-NC-ND 


\section{THE AFFIRMATION OF NOTHINGNESS}

distinctions. ${ }^{2}$ Encroaching beyond our anthropomorphic understanding of reality is a step towards the diminishment of the self's high regard. Returning to the challenge of Daoism abovementioned, overcoming the impossibility of knowing what is unknowable requires the decentralization of oneself. Such a process however is not a straightforward undertaking. In this essay, I present the humor of Zhuang Zi 莊子_as an affirmation of nothingness, not simply as an emptiness qua a lack of something but in a positive sense as a space for the transformation of things.

I do this in three steps. This begins with my treatment of the butterfly dream and the humorous conversation on the bridge over the Hao river as Zhuang Zi's challenge to question our perspectives. The transgressions between dreaming and waking states or between the fish and the human experience focus on a shift of the value of one's perspective. What I argue is that through these passages, Zhuang $\mathrm{Zi}$ makes one experience the transformation of things (wu hua 物化) as an invitation to each to embrace aesthetic values qua a sensitivity to reality than epistemic values as the reduction of experience to expressions conveyed by factual propositions. This then leads to my focus on the centrality of the Dao 道 qua the non-being of nothingness ( $w u w u$ 無無). What is vital here is the action of undercoming which implies a different type of action in relation to things. Grounding this to the Zhuangzi, I take up the conversation between the wheelwright and Duke Huan to portray how a mindless approach to reality allows one to mirror the nothingness in the Dao. Lastly, I then bridge this to Zhuang Zi's humor expressed through the event following the death of his wife which I ultimately argue is the articulation of his sensitivity to the transformation of things. Such genuineness in face of nothingness, makes one a genuine pretender, or better said following Hans-Georg Moeller and Paul J. D'Ambrosio, a zhenuin pretender, as Zhuang Zi manifests by his humor which affirms nothingness.

I

The Zhuangzi is fictionalist in presenting realist semantic conditions throughout the narrative at the same time that it distances itself from any definite meaning. ${ }^{3}$ It provides accounts of reality by narrating occurrences between characters or forces in nature, yet requires a sense of caution on part

2 See Liang Shi, "The Leopardskin of Dao and the Icon of Truth: Natural Birth versus Mimesis in Chinese and Western Literary Theories," in Comparative Literature Studies 31, no. 2 (1994), 152, <https://www.jstor.org/stable/40246930>.

${ }^{3}$ See Julianne Chung, "Taking Skepticism Seriously: How the Zhuang-Zi Can Inform Contemporary Epistemology," in Comparative Philosophy 8, no. 2 (2017), 5, $<$ https://core.ac.uk/download/pdf/145739164.pdf>

(c) 2021 Anton Heinrich L. Rennesland

https://www.kritike.org/journal/issue 28/rennesland1 june2021.pdf

ISSN 1908-7330

(cc) BY-NC-ND 
of the reader lest the words be taken too seriously. For this first section, I highlight how Zhuang $\mathrm{Zi}$ challenges one's perspective which is vital to reunderstanding life, and ultimately, affirm nothingness. I begin with the butterfly dream:

Once Zhuang Zhou dreamt he was a butterfly, fluttering about joyfully just as a butterfly would. He followed his whims exactly as he liked and knew nothing about Zhuang Zhou. Suddenly he awoke and there he was, the startled Zhuang Zhou in the flesh. He did not know if Zhou had been dreaming he was a butterfly, or if a butterfly was now dreaming it was Zhou. Now surely Zhou and a butterfly count as two distinct identities, as two quite different beings! And just this is what is meant when we speak of transformation of any one being into another-of the transformation of all things. ${ }^{4}$

The ability to approach the dichotomized states of being a butterfly and a human person is made possible by a fictionalist perspective. Zhuang $\mathrm{Zi}$ posits a transgression of the demarcated dreaming and the waking states by questioning who in fact was dreaming. This dream-story can be viewed as an overlap of oppositional concepts within the realm of epistemic value such as truth-untruth, reality-non-reality, and conscious-unconscious. These logical differences are obviously divided in the story through the clearly defined dreaming- and waking-state. The underlying question which may seem futile to ask is if it is Zhuang $\mathrm{Zi}$ or the butterfly dreaming. Any would readily answer that it is Zhuang Zi dreaming and not the obverse for the latter's lack of metacognitive abilities. Yet, the inability to suppose the second narrative presents a bias to the dominant one-not due to science's findings but an internal rejection of that possibility. It is just something that we seem sure to

${ }^{4}$ Zhuang Zi, Zhuangzi: The Complete Writings, ed. by Brook Ziporyn (Indianapolis: Hackett Publishing Company, 2020), II. One may refer to this passage in several ways depending on the context, which I argue each highlights a particular element: dream-story, butterfly dream, or dream argument. As dream-story, the fictional element come with stress given to the fictitious element of the tale. As butterfly dream, there is this fluidity between the differed states of butterfly and man-The protagonist becomes the butterfly and it in itself is the butterfly dreaming and the object of the dream. As dream argument, it signifies an inherent argumentative character that serves as the overall position of this paper. I understand Robert Allison's reading of enlightenment as the butterfly transgresses the dichotomized states, yet I would rather side with Kai-Yuan Cheng that there is a substantial thesis contained in the dream (Cf. Robert E. Allinson, Chuang-Tzu for Spiritual Transformation: An Analysis of the Inner Chapters (Albany: State University of New York Press, 1989), 89ff. and Kai-Yuan Cheng, Self and The Dream of the Butterfly in the "Zhuangzi"," in Philosophy East and West 64, no. 3 (July 2014), 582-585, $<$ https://www.jstor.org/stable/43285902>. 


\section{THE AFFIRMATION OF NOTHINGNESS}

know because of what we have experienced: I, a human person, dream. Our reluctance to consider the second narrative bears testament of the need for Zhuang Zi's radical uncertainty. ${ }^{5} \mathrm{One}^{\prime}$ 's unwillingness to suggest the butterfly dreaming is rooted in the security one has in logical reasoning which has conditioned our perspective.

This anecdote may serve as a reminder of the plasticity of one's own perspective for the transgression of states or the transformation of things. When invoking perspectives, Zhuang $\mathrm{Zi}$ signifies their transformation for "our social reality is the product of the human intellect, and the dominance of our intellect is the source of a kind of spiritual static [that] builds up, takes form and is perpetuated in social, ethical and aesthetic systems which obscure and eventually block our view of the Dao." ${ }^{\prime \prime}$ How one responds to the dream story is fundamentally connected to one's general perspective since perspectives build upon each other. Social reality is built upon even the tiniest of epistemic groundings. This dream story seeks to present the transformation of states as a challenge to the fixed perspectives that are based upon solely epistemic (factual) values that may led to a dogmatic approach to life.

Reconsidering the impossibility of the second narrative is something peculiar to Zhuang Zi's stories. We may observe this in the deeply humored conversation between Zhuang Zi and Hui Zi 惠子:

Zhuangzi and Huizi were strolling along the bridge over the Hao River. Zhuangzi said, "The minnows swim about so freely, following the openings wherever they take them. Such is the happiness of fish."

Huizi said, "You are not a fish, so whence do you know the happiness of fish?"

Zhuangzi said, "You are not I, so whence do you know I don't know the happiness of fish?"

Huizi said, "I am not you, to be sure, so I don't know what it is to be you. But by the same token, since you are certainly not a fish, my point about your inability to know the happiness of fish stands intact."

Zhuangzi said, "Let's go back to the starting point. You said, 'Whence do you know the happiness of fish?' Since your question was premised on your

\footnotetext{
${ }^{5}$ See Raymond Tallis, "Zhuangzi and that Bloody Butterfly," Philosophy Now: A Magazine of Ideas (2009), <https://philosophynow.org/issues/76/Zhuangzi_And_That_Bloody_Butterfly>.

${ }^{6}$ Philip J. Ivanhoe, "Zhuangzi on Skepticism, Skill, and the Ineffable Dao," in Journal of the American Academy of Religion 61, no. 4 (Winter 1993), 645, $<$ https://www.jstor.org/stable/1465056>.

(c) 2021 Anton Heinrich L. Rennesland https://www.kritike.org/journal/issue 28/rennesland1 june2021.pdf ISSN 1908-7330
}

(c) BY-NC-ND 
knowing that I know it, I must know it from right here, up above the Hao River."7

The play of conclusions between the two is proof of the difference of their perspectives. The character an 安 is indicative of several questions such as when, how, or where. ${ }^{8}$ As Hui Zi asks how, Zhuang Zi replies where. Their misunderstanding is due to their different approach to the matter: Zhuang $\mathrm{Zi}$ focuses on the actual experience of happiness, the freedom of the fish; Hui $\mathrm{Zi}$ reduces the dialogue to facticity, equating the pure experiences of happiness and freedom to linguistic expressions as if the expressions may be aptly conveyed through such. ${ }^{9}$ Reducing the context of the discussion to facticity or by highlighting the epistemic content does not equate to a more holistic approach to understand the experience. Hui $\mathrm{Zi}^{\prime}$ s inquiry desaturates the actual experience that Zhuang $\mathrm{Zi}$ wishes to convey.

In reality, we are mindful that the waking and dreaming states are distinguishable such as under and over the Hao. What is not assured though is our ability to always verify the divergence without any error. ${ }^{10}$ With the stories of the butterfly and the fish, we are left with two narratives-dreaming and waking; under and over the Hao-ironically, and contrary to an initial speculation, not in opposition. Zhuang $\mathrm{Zi}$ presents these states not for us to consider them in opposition to each other but to widen our economy of thought through the transgressions of our experiences. This is radically different from Hui Zi's reduction of experience to facticity. While Hui $\mathrm{Zi}$ stresses the epistemic value, Zhuang Zi seeks to stress the aesthetic (sensitive) value of the experience. Emphasizing this sensitizes one's perspective to the natural world, not in the sense of imposing one's perspective onto it but of integrating oneself to the non-human environment. ${ }^{11}$ Such a sensitivity rooted in aesthetic value goes beyond the identical relationship of thoughts and objects for these are expressions of epistemic value and are subject to anthropological variances and inclinations. Zhuang $\mathrm{Zi}$ challenges our perspective to embrace the free-flowing creativity of experiencing reality.

\footnotetext{
${ }^{7}$ Zhuang Zi, Zhuangzi, XVII.

${ }^{8}$ See James D. Sellmann, "Transformational Humor in the Zhuangzi," Wandering at Ease in the Zhuangzi, ed. by Roger T. Ames (Albany: State University of New York Press, 1998), 168.

${ }^{9}$ See Eske Møllgaard, An Introduction to Daoist Thought: Action, Language, and Ethics in Zhuangzi (New York: Routledge, 2007), 83 and Zhaohua Chu, "On the Constitution and the True Aim of "The Joy of Heaven" and "Non-Speech": A Reinterpretation of the Debate at the Dam over the Hao River," in Frontiers of Philosophy in China 9, no. 4 (December 2014), 563, $<$ https://doi.org/10.3868/s030-003-014-0046-9>.

${ }^{10}$ See Ivanhoe, "Zhuangzi on Skepticism, Skill, and the Ineffable Dao," 642.

${ }^{11}$ See Hans-Georg Moeller, "Hundun's Mistake: Satire and Sanity in the Zhuangzi," in Philosophy East and West 67, no. 3 (July 2017), 788, < https://muse.jhu.edu/article/664495>.
}

(c) 2021 Anton Heinrich L. Rennesland https://www.kritike.org/journal/issue 28/rennesland1 june2021.pdf

ISSN 1908-7330 


\section{THE AFFIRMATION OF NOTHINGNESS}

This leads one to go beyond the self-imposed constraints that stem from a sealed heart-mind ( $x$ in 心) due to the preponderance of a single perspective..$^{12}$

Zhuang $\mathrm{Zi}$ points to the fact that a human-centered life is a dream that one must constantly wake up from lest it become a reified experience..$^{13}$ The tendency for knowledge-what, when, where, how-to transgress dichotomized states presents a glimpse of the Dao, similar to the continuity from under and above the Hao, from butterfly to human. The butterfly soars beyond the dualist economy of rational thought just as the fish swims under and over the Hao. Zhuang Zi's fictionalist standpoint engenders the transformation of perspectives and even of speech. ${ }^{14}$ However, ultimately, it is a transformation of the self's centrality to something greater. The creativity of correlative thinking, the ironic dependence of each extreme, challenges one to reconsider the ostensible antagonism in the first place. The moment of awakening and the utter confusion of who was dreaming what which follows reveal a discrepancy in the divided states, which becomes the vantage point for the transformation of things, a shift of the ground of one's perspective from epistemic to aesthetic value.

\section{II}

Zhuang $\mathrm{Zi}$ would rather consider oppositional states as complementary pairs to provide a perspective of a harmonized view of life tied together by the transformation of things. What causes distress in approaching the transgression is not the inability to distinguish the dichotomies but the "anthropomorphic uncertainty" of not always knowing "who or what one truly is." 15 Anxiety lies at the transgression of dichotomized states. It is found in the process of becoming, the crossing over from one to another. Rather than a staunch opposition, a better response is to accept the inability of language to grasp this experience and to embrace becoming; not thinking with the animal but becoming the animal. This allows

\footnotetext{
12 See Chen Guying, "Zhuang Zi and Nietzsche: Plays of Perspectives," trans. by James D. Sellmann, Nietzsche and Asian Thought, ed. by Graham Parkes (Chicago: University of Chicago Press, 1991), 124.

${ }^{13}$ See Møllgaard, An Introduction to Daoist Thought, 19.

${ }_{14} \mathrm{Chu}$ presents a great discussion on what I could consider as the "transvaluation of speech' that Zhuang Zi prompts. Zhuang Zi was aware of the limitations of "small speech" and his "conclusive critique of the limitations of small speech and ordinary speech constitutes a major trend in his thought and has attracted much attention, but it is only one aspect of his thought. Zhuang $\mathrm{Zi}$ had unique thoughts and answers from another perspective." (Chu, "On the Constitution and the True Aim of "The Joy of Heaven" and "Non-Speech," 567) The differed perspective may also be attributable to the shift in discourse's trajectory that finds root ultimately in the use of speech or of language.

${ }^{15}$ Irving Goh, "CHUANG TZU'S BECOMING-ANIMAL," in Philosophy East and West 61, no. 1 (January 2011), 112, < https://www.jstor.org/stable/23015257>.
}

(C) 2021 Anton Heinrich L. Rennesland

https://www.kritike.org/journal/issue 28/rennesland1 june2021.pdf

ISSN 1908-7330

(cc) BY-NC-ND 
a gradation between stories: the butterfly's suspicion to the fish's happiness. Parenthetically, we may also notice how in the narratives in the Zhuangzi, there is a lack of the personal pronoun in the former, which is affirmed in the latter ("I know it."). As pointed out in the humored conversation between Zhuang $\mathrm{Zi}$ and Hui $\mathrm{Zi}$, the fish is without anxiety for it swims peacefully, without any knowledge of the limits set forth by nature. ${ }^{16}$ Instead of seeing water as the fish's limitation, one may opt to understand the freedom it offers to it instead, attributable also to air in respect to the butterfly. When Zhuang $\mathrm{Zi}$ speaks of the transformation of things, he decenters the self and overcomes the limits imposed upon this self. I opt to use the verb of undercoming following Hans-Georg Moeller's Daoist critique of humanism levied against Confucian ritualism and is addressed to the totality of Being, to use the Western jargon; it speaks with no identity, with no single human voice. ${ }^{17}$ The lack of that singular voice signifies that lack of the prejudice for a certain sense of fulfilment, i.e., a human flourishing according to set patterns. Undercoming in this sense neither follows any formula nor goes beyond (overcomes) the distinctions. The Daoist sage proceeds via a different path of undercoming for he understands the Dao not as a cosmic plan to be realized but an immanent order for things to naturally proceed.18 Undercoming implies a certain sense of attention to spontaneity or the self-so (ziran 自然), of allowing things for naturally proceed instead of imposing oppositional pairs.

To discuss this further, I turn our attention to Chapter 13 of the Zhuangzi which begins with an equation of the courses of heaven (tian 天), emperor ( $d i$ 帝), and sage (sheng 圣) that circulate without accumulation because, it says, they have a peaceful mind. ${ }^{19}$ The value that the three get from their respective paths is not due to any possession or gain but a reluctancy of aspiring for such. The section continues, "The stillness of a sage's mind is a looking glass for heaven and earth, a mirror for the ten thousand things. This emptiness and stillness, this placidity and flavorlessness, this silence and quiescence, this non-doing is the even level of heaven and earth, the full realization of the Course and its intrinsic powers." 20 We may draw affinities between what we read from the Zhuangzi here to the ending of the Daodejing: "Someone who does good does not go in for quantity [while] Someone who

\footnotetext{
${ }^{16}$ See Chu, "On the Constitution and the True Aim of "The Joy of Heaven" and "NonSpeech," 560.

17 See Hans-Georg Moeller, The Philosophy of the Daodejing (New York: Columbia University Press, 2006), 137.

${ }^{18}$ See Ibid., 48.

${ }^{19}$ See Zhuang Zi, Zhuangzi, XIII.

${ }^{20} \mathrm{Ibid}$.
}

(c) 2021 Anton Heinrich L. Rennesland https://www.kritike.org/journal/issue 28/rennesland1 june2021.pdf

ISSN 1908-7330 


\section{THE AFFIRMATION OF NOTHINGNESS}

goes in for quantity does no good." 21 The Dao does not accumulate in its path since accumulation makes it enter into a world of opposition-having-nothaving, accumulation-diminution. The Dao's stillness is due to its nonengagement of this logic, due to its undercoming. It is an emptiness that signifies a receptivity to a goodness absent in both accumulation and diminution, an imperturbability in face of motion, and a nothingness that is responded to by non-doing ( $w u$ wei 無為) which stands as the source of everything.

This is ultimately summed by the chapter's last illustration. ${ }^{22}$ The conversation between Duke Huan and Wheelwright Flatty begins with the latter's inquisitiveness of what the former was reading. With the duke's response that it was the teachings of dead sages, the wheelwright exclaimed that such is rubbish, which the former disputed and confronted the latter to justify lest he be killed. The narrative ends without an affirmation if the wheelwright's response was acceptable to the duke, as we, readers of the Zhuangzi, are left to playfully imagine if such is a worthy justification: The wheeler explains to the duke that he has to find the balance between spinning the wheel slowly and quickly - too slow and it attaches loosely, too quick, too tight. The difficulty is finding a balance knowable not by speech but by feeling. This experience is something, he admits, that he cannot even convey to his own son. The wheeler responds to the duke that the latter's reading of the deceased sages' wisdom is futile since, besides the fact that words are unable to convey the entirety of experience, these individuals are already dead. We are left to wonder if the wheelwright would have answered the same if the duke's book contained sayings from living sages instead. If the words of the living would not have received the same response from him, it seems paradoxical for he attests to the inefficacy of words through his experience of failing to enlighten his son. On the contrary, if the wheeler still criticizes the duke for reading the words of living sages, it gives the impression that the wheeler just had the penchant to stir up a conversation.

We are left with no clue as to what happened after the response, yet the paradoxical nature, as I have pointed out, perhaps gives flesh to the sentences prior to the story:

For whatever we can see by looking is only shapes and forms. Whatever we can hear by listening is only names and sounds. Alas! This age takes shapes, forms, names, and sounds as sufficient to attain the reality of that

\footnotetext{
${ }^{21}$ Lao Zi, Daodejing, 81.3-81.4, in Rudolf G. Wagner, A Chinese Reading of the Daodejing: Wang Bi's Commentary on the Laozi with Critical Text and Translation (Albany: State University of New York Press, 2003), 386.

${ }^{22}$ See Zhuang Zi, Zhuangzi, XIII.

(c) 2021 Anton Heinrich L. Rennesland

https://www.kritike.org/journal/issue 28/rennesland1 june2021.pdf

ISSN 1908-7330
}

(c) BY-NC-ND 
something else. But shapes, forms, names and sounds are ultimately not sufficient to get at what is real there. Thus 'those who know do not speak, and those who speak do not know.' But how could the present age understand this!23

Those who know do not communicate, while those who do speak are ignorant. This is evocative of the opening lines of the Daodejing to which Geling Shang provides a commentary that the Dao that can be Dao-ed is not the Dao since language cannot entirely present a way $(D a o)$ to orally transmit (Dao, as opposed to written language, ming 名) the path (Dao) to knowledge. ${ }^{24}$ The inability to fully articulate experience highlights the nothingness that the Dao engenders. This though ought not to be simply reduced to the Buddhist sunyata for such an equation "would starve Dao of its existence as the wellspring of onto-cosmological generation and return." 25 Reality is not simply the shapes and sounds we encounter on a daily basis but something much greater than these. Conversely, approaching the Dao does not just mean an interior emptiness for this fails to capture the metaphysical totality which the Dao provides.

I opine that what one gets from the wheeler's admonition is the inability to forget oneself and to realize the centrality of nothingness to reality. The failure of the duke is his inability to forget himself since he was reading wise words of past sages to appropriate their practices to his own life. This seems rather contrary to ziran, a realization of the immanent progression according to nature. The futility of words does not simply signify the inability of speech but our failure to engage in non-action through such an activity. Zhuang Zi's pondering is articulated by Brook Ziporyn:

To consciously weigh alternatives, apply your understanding to making a decision about what is best, and then deliberately follow the course you have decided on-this is the fundamental structure of all purposive activity and conscious knowledge, the basis of all ethics, all philosophy, all politics, all human endeavors at improvement, and this is precisely what Zhuangzi seems to consider ridiculous and impossible.

${ }^{23}$ Zhuang Zi, Zhuangzi, XIII.

${ }^{24}$ See Geling Shang, "Embracing Differences and Many: The Signification of One in Zhuangzi's Utterance of Dao," in Dao: A Journal of Comparative Philosophy, 1, no. 2 (June 2002), 231-232, <http://dx.doi.org/10.1007/BF02857097>.

25 David Chai, "Daoism and $W u$ 無" in Philosophy Compass 9, no. 10 (2014), 665, $<$ https://doi.org/10.1111/phc3.12171>.

(c) 2021 Anton Heinrich L. Rennesland https://www.kritike.org/journal/issue 28/rennesland1 june2021.pdf

ISSN 1908-7330 


\section{THE AFFIRMATION OF NOTHINGNESS}

Knowledge is unreliable; Will is unreliable; Tradition is unreliable; Intuition is unreliable; Logic is unreliable; Faith is unreliable. But what else is there? ${ }^{26}$

The rational process involved in speaking and in leaning is unreliable since doing so reminds us of the self at the expense of mindlessness in ziran and ultimately of the Dao. What Zhuang Zi seeks to point out is not the blanket meaninglessness of our endeavors but the folly of humanity in failing to decenter, or more radically, to forget oneself. The Daoist sage empties and forgets himself to mirror the nothingness which, "as the onto-cosmical fabric of Dao's creative potential, enfolds non-being as part of its own selftransformation." 27 Nothingness plays a crucial role in understanding the Dao. This is in fact even given emphasis by the double negation of $w u w u$ 無無 that may be translated as the non-being of nothingness in the Zhuangzi.28 This signifies not just the non-metaphysical status of $w u$ or a solipsism that results from a negation of the object but, Chai notes, as "a self-negating solipsism" that frees the individual from discriminatory reality, and radically, a dynamic release "from our epistemological or phenomenological grasping while symbolically entailing its living presence." 29 The inability of the duke to learn from the words of the past sages, similar to the wheeler's son, stems from a separation of consciousness from lived experience, the $I$ from everything else. What the Zhuangzi passages present is not the emphasis on the individual but, in fact, the disappearance of the self as it reflects the nothingness central to the Dao. The self transforms: becomes as it undercomes reality, as it is released from self-imposed restrictions due to epistemic value.

What Zhuang $\mathrm{Zi}$ signifies with the transformation of things is his rejection of the false dilemma attributed to life. ${ }^{30}$ For him, life-praxis is "a holistic state of being in which the mind and body fuse into one, and the individual comes to possess a form of meta-consciousness through which the internalization of all outward forms of awareness become one ineffable state of existence." 31 Life is a constant engagement, a praxis outside the separation of consciousness and materiality. If we understand humanity as simply life, then we are misguided. Life is a harmony given by both heaven and earth ( $d i$

\footnotetext{
${ }^{26}$ Brook Ziporyn, Introduction to Zhuang Zi, Zhuangzi: The Essential Writings, trans. by Brook Ziporyn (Indianapolis: Hackett Publishing Company, 2009).

${ }^{27}$ Chai, Zhuangzi and The Becoming of Nothingness, 6.

${ }^{28}$ See Zhuang Zi, Zhuangzi, XXII.

${ }^{29}$ Chai, Zhuangzi and The Becoming of Nothingness, 9.

30 See Sandra A. Wawrytko, Deconstructing Deconstruction: Zhuang Zi as Butterfly, Nietzsche as Gadfly," in Philosophy East and West, 58, no. 4 (October 2008), 526, < https://doi.org/10.1353/pew.0.0026>.

${ }^{31}$ Chai, Zhuangzi and The Becoming of Nothingness, 49.
}

(c) 2021 Anton Heinrich L. Rennesland

https://www.kritike.org/journal/issue 28/rennesland1 june2021.pdf

ISSN 1908-7330

(c) ) BY-NC-ND 
地), and is never one's own possession. ${ }^{32}$ What we ought to aspire to reflect with our own lives is the nothingness that comprises the whole of reality. In one not being one's own possession, Zhuang Zi provides the link of heaven, earth and humanity (ren 人). Humanity here serves as a reference to a certain non-reflexive reflectivity that engenders not a focus on subjectivity but its undercoming.

III

Having presented the Zhuangzi as an invitation for a differed perspective (section 1) which leads to a mindlessness that reflects the nothingness in the Dao (section 2), I devote the remaining part of this essay to present Zhuang Zi's humor as an affirmation of nothingness. His humor is not something unknown. Xiao Dong Yue ties Zhuang Zi's appreciation of paradoxes which he shares with Lao $\mathrm{Zi}$, to a wild and grand display of humor through tricks, games, and sarcasms that is particularly Zhuang Zi's. ${ }^{33}$ In the face of life's apparent contradictions, Zhuang Zi's response is his known humor and jest. ${ }^{34}$ Dwelling deeper on the literary expressions, what the Zhuangzi conveys are transformations that seek to deconstruct the clear-cut boundaries of "being, thinking, feeling, speaking, and acting" which are aimed at stimulating a change within the reader. ${ }^{35}$ In following Zhuang Zi's narratives, one finds oneself adopting the narrative's logic only to be caught in a number of consequences. Moeller and D'Ambrosio provide six characteristic of humorist communication in the Zhuangzi:

(1) a disengaging effect that distances us from a serious situation or the serious protagonists of a narrative; (2) a narrative contradiction or disappointment of initially provoked expectations that is brought about by (3) instances of incongruity typically produced by paradoxical, ironic, or nonsensical statements; (4) a relaxation of strenuous or strong emotions; and (5) an experience of pleasure resulting from this relaxation as

32 Zhuang Zi, Zhuangzi, XXII.

${ }^{33}$ See Xiao Dong Yue, "Exploration of Chinese Humor: Historical Review, Empirical Findings, and Critical Reflections," in Humor - International Journal of Humor Research 23, no. 3 (August 2010), 405 and 409, <https://doi.org/10.1515/humr.2010.018>.

${ }^{34}$ See Sellman, "Transformational Humor in the Zhuangzi," 167 and Alfredo P. Co, "HERMENEUTICS OF THE GENIUS OF THE ABSURD: Interpreting the Dao," in Across the Philosophical World: Essays in Comparative Philosophy (Manila: UST Publishing House, 2009), 3942.

${ }^{35}$ See Sellmann, "Transformational Humor in the Zhuangzi," 167.

(C) 2021 Anton Heinrich L. Rennesland https://www.kritike.org/journal/issue 28/rennesland1 june2021.pdf

ISSN 1908-7330 


\section{THE AFFIRMATION OF NOTHINGNESS}

well as from (6) the saving of mental efforts or the experience of mental effortlessness. ${ }^{36}$

These characteristics showcase the depth of Zhuang Zi's humor that is much greater than what we might immediately associate as slapstick comedy. In an analysis of the latter, Žižek recognizes a suspension of the normal course of events-such as cartoon portrayals of a dancer that momentarily does not stop spinning or a cat thrown in the air that remains afloat for an extended period of time-that presented to the viewers a suspended animation. ${ }^{37}$ What is shared by Zhuang Zi's humor and this type of comedy is the suspension of life, anima. If one were to look closely at these two words suspended animation, one would recognize a contradiction. To suspend comes from the Latin suspendere which means to hang (to kill), to interrupt, or to set aside. In the context of suspended animation, what is set aside is the very principle of life, anima, that is ironically revealed with motion. It kills the anima. Suspended animation renders motion motionless, life unalive. This signals an interruption of the grammar of our experience, something that we admit to be found in the Zhuangzi. However, their obvious difference is realized when we analyze from where the humor stems. The paradoxical nature of suspended animation through the examples of the dancer still spinning and the cat hovering differs from Zhuang $\mathrm{Zi}$ for the suspension of the natural movement of both dancer and cat brings the focus to themselves as exaggerated performers or cartoon characters, unlike in the Zhuangzi which decenters oneself. Zhuang Zi's humor offers a genuineness (zhen 真) that shows one's relation to the totality of reality. Through his humor, Zhuang $\mathrm{Zi}$ becomes, to borrow the phrase from Moeller and D'Ambrosio, a "zhenuine pretender." 38 The Zhuangzi's zhenuine characters demonstrate the transformation of things. The seemingly serious narrative turns comical in a sudden relaxation; the reader becomes disengaged from the sparing of logical statements and experiences a pleasure derived from not understanding but from the sensitivity to the experience itself. The humor shifts the value from facticity to aesthetic. Humor is found in the serenity of effortless engagement as the reader is led not to focus on the protagonist's suspended motion but on the nothingness that lies behind the zhenuine pretenders.

To emphasize this point, one may recall the interesting scene following the death of Zhuang Zi's wife:

\footnotetext{
${ }^{36}$ Hans-Georg Moeller and Paul J. D' Ambrosio, Genuine Pretending: On the Philosophy of the Zhuangzi (New York: Columbia University Press, 2017), §III.

${ }^{37}$ See Slavoj Žižek, The Parallax View (Cambridge, Massachusetts: MIT Press, 2006), 63.

${ }^{38}$ Moeller and D'Ambrosio, Genuine Pretending, §Conclusion.
} 
When Zhuangzi's wife died, Huizi went to offer his condolences. He found Zhuangzi squatting on the floor singing, accompanying himself by pounding on an overturned washtub held between his splayed legs.

Huizi said, "You live with someone, raise children with her, grow old with her-not crying over her death is enough already, isn't it? But to go so far as to pound on a washtub and sing, isn't that going too far?"

Zhuangzi said, "No, it's not. When this one first died, how could I not feel grief just like anyone else? But then I considered closely how it had all begun: previously, before she was born, there was no life there. Not only no life: no physical form. Not only no physical form: not even energy. Then in the course of some heedless mingling mishmash a change occurred and there was energy, and then this energy changed and there was a physical form, and then this form changed and there was life. Now there has been another change and she is dead. This is how she participates in the making of the spring and the autumn, of the winter and the summer. For the moment a human lies stiffened here, slumbering in this enormous house. And yet there I was getting all weepy, even going on to wail over her. Even to myself I looked like someone without any understanding of fate. So I stopped." 39

In such a situation, the proper conduct ( $l i$ 禮) would demand bereavement which is a constitute role according to Meng Zi 孟子 who equated ritualized mourning as a pillar of a civilized society. ${ }^{40} \mathrm{Hui} \mathrm{Zi}$ points this out to Zhuang $\mathrm{Zi}$, who according to him transgresses the custom. However, the widower's zestful response suggests his critique of the Confucian emphasis of $l i$. His dynamic experience affirms the nothingness behind the confining Confucian ming and li. This passage does not portray a Zhuang $\mathrm{Zi}$ that is cynical in his wife's passing but as a zhenuine pretender in having understood what life genuinely is.

The death of Zhuang Zi's wife presents the transition from a fear of life's end to a joviality in recognizing the abundance of life which continues beyond what we merely understand. Death is usually considered as the end

${ }^{39}$ Zhuang Zi, Zhuangzi, XVIII.

40 See Albert Galvany, "Distorting the Rule of Seriousness: Laughter, Death, and Friendship in the Zhuangzi," in Dao 8 (2009), 55-56, <https://doi.org/10.1007/s11712-008-9098-1>.

(c) 2021 Anton Heinrich L. Rennesland https://www.kritike.org/journal/issue 28/rennesland1 june2021.pdf

ISSN 1908-7330 


\section{THE AFFIRMATION OF NOTHINGNESS}

of a lengthy series of transformations or, à la Heidegger, as the possibility of impossibility. ${ }^{41}$ Death stands as life's end, and this vests greater meaning when we consider the end qua in process of formation (Gestaltung) as the completion of the process while signifying a break from it (such as breaking off or away). ${ }^{42}$ Considering life as the time geared towards death is something that Zhuang $\mathrm{Zi}$ would consider as a misunderstanding of the transformation of things. Zhuang Zi's admonition of the transformation is not a pompous reproach to live life to the fullest but is a realization that is fundamentally characterized by a plasticity reflecting the ever-changing flux potent in nothingness. Zhuang $\mathrm{Zi}$ is a pretender-not pretending in order to deceive but pretending because he understands what life truly is. It is a pretention that "allows one to enjoy with unquestioned ease 'foreign' existences and capacities and to get along with what happens in a situation[.]" 43 It is at this type of existence that, similar to the butterfly in the dream or the fish in the water, happiness is found in the freedom of living without the immunized zones demarcated by logic's arbitrary imposition. Death and life may be taken for each other such as the dreaming and waking states. ${ }^{44}$ Zhuang Zi's light-heartedness opens the readers to a freedom that allows them to move along with the transformation of things. ${ }^{45} \mathrm{He}$ upholds his joviality even in face of the ultimate end of existence, for he is mindless of existence as we know it and understands that life is never fully one's own. One is left to genuinely pretend throughout the course of existence, not to sink into despair but to experience the transformation of things and in fact affirm the nothingness behind it.

What Zhuang $\mathrm{Zi}$ affirms with his humor is a sensitivity to the complexity of life. This complexity stems not from the arbitrary imposition of logical standards but the ever-changing reality manifested by the transformation of things. His humor demonstrates how life is full of differences that cannot be reduced to each other but ought to be undercome to see the bigger picture of the nothingness behind. Throughout the Zhuangzi, the humorous conversation between the various characters "breaks down traditional habits of abstract impersonal thinking, challenging the audience

\footnotetext{
${ }^{41}$ See Ibid., 55 and Martin Heidegger, Sein und Zeit, in Heidegger Gesamtausgabe, Bd. 2 (Frankfurt am Main: Klostermann, 1967), 348.

42 See Martin Heidegger, Der Begriff der Zeit, in Heidegger Gesamtausgabe, Bd. 64 (Frankfurt am Main: Klostermann, 2004), 47.

${ }^{43}$ Moeller and D'Ambrosio, Genuine Pretending, §Conclusion.

${ }^{44}$ See Graham Parkes, "In the Light of Heaven before Sunrise: Zhuangzi and Nietzsche on Transperspectival Experience," in Daoist Encounters with Phenomenology: Thinking Interculturally about Human Existence, ed. by David Chai (London: Bloomsbury Academic, 2020), 75.

45 See Youru Wang, Linguistic Strategies in Daoist Zhuangzi and Chan Buddhism: The Other Way of Speaking (London: RoutledgeCurzon, 2003), 159.
}

(c) 2021 Anton Heinrich L. Rennesland https://www.kritike.org/journal/issue 28/rennesland1 june2021.pdf ISSN 1908-7330

(cc) BY-NC-ND 
to think anew." 46 It undercomes the apparent dichotomy and affirms the differences that each represent, not for each singularity to be focused upon such in the case of slapstick humor but to be mindless of the difference and to appreciate the flow between them. Zhuang $\mathrm{Zi}$ laughs as he experiences the nothingness which life is part of and consequently as he finds his proper place between heaven and earth.

The butterfly story in hindsight is indeed a laughable matter, just like a caricature of Zhuang $\mathrm{Zi}$ actually becoming the animal. The ridicule is on the person who takes these too seriously. The practical thing that we get from these stories is the ability to laugh-and to laugh repeatedly. Repeated activities provide a glimpse of the Dao. ${ }^{47}$ Repeated laughter presents the ability to resolve conflicts between perspectives - and eventually to act beyond the repetition, to act without acting, to laugh without laughing. Between epistemic dogmatism and skepticism, learning to laugh from the Zhuangzi is an activity of non-activity, a mindlessness that decenters oneself and mirrors the nothingness of the Dao. Zhuang $\mathrm{Zi}$ challenges each to question one's perspectives and to uncover for themselves the possibility to dance with life to the beat of his drum. "Rather than letting the roles that we have to play define us from the inside out, we may play them lightly and effortlessly, and with skill and grace." 48 The freedom that may be located in the humor of Zhuang $\mathrm{Zi}$ allows one to play with reality. ${ }^{49} \mathrm{It}$ is a freedom to continuously create better perspectives focused on nothingness. Rather paradigmatically, we are reminded of the words of Nietzsche: "Creating that is the great redemption from suffering, and life's becoming light. But in order for the creator to be, suffering is needed and much transformation." 50 This highlights the suffering one endures in shifting one's perspective and the continuous transgressions in the transformation of things. At the end, one sees that "Zhuang $Z i$ is a fluttering yin butterfly, who invites us to play[.]"51 Zhuang $\mathrm{Zi}$ is the yin 陰 to our respective life-praxis which stands as yang 陽. As yin, Zhuang Zi makes obscure something that we thought was clear. He stands as the cloud for us to realize the immensity of the sky, that goes beyond

${ }^{46}$ Sellmann, "Transformational Humor in the Zhuangzi," 168.

${ }^{47}$ See Møllgaard, An Introduction to Daoist Thought, 38.

${ }^{48}$ Moeller, “Hundun's Mistake," 796.

${ }^{49}$ Wawrytko, "Deconstructing Deconstruction," 530.

${ }^{50}$ Friedrich Nietzsche, Thus Spoke Zarathustra: A Book for All and None, ed. by Adrian Del Caro and Robert B. Pippin, trans. by Adrian Del Caro (Cambridge: Cambridge University Press, 2006), 66.

${ }^{51}$ Wawrytko, "Deconstructing Deconstruction," 526.

(c) 2021 Anton Heinrich L. Rennesland https://www.kritike.org/journal/issue 28/rennesland1 june2021.pdf

ISSN 1908-7330 


\section{THE AFFIRMATION OF NOTHINGNESS}

the azure that we see. ${ }^{52} \mathrm{He}$ invites us to laugh, to get rid of the confinements of our mind and to undercome our experiences. The butterfly has now flown into the recesses of our imagination, awaiting our response to its invitation for nothingness' affirmation.

Department of Philosophy, University of Santo Tomas, Philippines

\section{References}

Allinson, Robert E., Chuang-Tzu for Spiritual Transformation: An Analysis of the Inner Chapters (Albany: State University of New York Press, 1989).

Chai, David, “Daoism and Wu 無” in Philosophy Compass, 9, no. 10 (2014), 663671, <https://doi.org/10.1111/phc3.12171>. Zhuangzi and The Becoming of Nothingness (Albany: State University of New York Press, 2019).

Chen Guying, "Zhuang Zi and Nietzsche: Plays of Perspectives," trans. by James D. Sellmann, Nietzsche and Asian Thought, ed. by Graham Parkes (Chicago: University of Chicago Press, 1991).

Cheng, Kai-Yuan, "Self and The Dream of the Butterfly in the "Zhuangzi"," in Philosophy East and West, 64, no. 3 (July 2014), 563-597.

$\mathrm{Chu}$, Zhaohua, "On the Constitution and the True Aim of "The Joy of Heaven" and "Non-Speech": A Reinterpretation of the Debate at the Dam over the Hao River," in Frontiers of Philosophy in China, 9, no. 4 (December 2014), <https://doi.org/10.3868/s030-003-014-0046-9>.

Chung, Julianne, "Taking Skepticism Seriously: How the Zhuang-Zi Can Inform Contemporary Epistemology," in Comparative Philosophy, 8, no. 2 (2017), 3-29, <https://core.ac.uk/download/pdf/145739164.pdf>.

Co, Alfredo P., "HERMENEUTICS OF THE GENIUS OF THE ABSURD: Interpreting the Dao," in Across the Philosophical World: Essays in Comparative Philosophy (Manila: UST Publishing House, 2009).

Galvany, Albert, "Distorting the Rule of Seriousness: Laughter, Death, and Friendship in the Zhuangzi," in Dao, 8 (2009), 49-59, $<$ https://doi.org/10.1007/s11712-008-9098-1>.

Goh, Irving, "CHUANG TZU'S BECOMING-ANIMAL," in Philosophy East and West, 61, no. 1 (January 2011), 110-133.

Heidegger, Martin, Der Begriff der Zeit, in Heidegger Gesamtausgabe, Bd. 64 (Frankfurt am Main: Klostermann, 2004). Sein und Zeit, in Heidegger Gesamtausgabe, Bd. 2 (Frankfurt am Main: Klostermann, 1967).

${ }^{52}$ See Zhuang Zi, Zhuangzi, I.

(c) 2021 Anton Heinrich L. Rennesland https://www.kritike.org/journal/issue 28/rennesland1 june2021.pdf ISSN 1908-7330

(c) $)$ BY-NC-ND 


\section{A. RENNESLAND 91}

Ivanhoe, Philip J. "Zhuangzi on Skepticism, Skill, and the Ineffable Dao," in Journal of the American Academy of Religion, 61, no. 4 (Winter 1993), 639654.

Moeller, Hans-Georg, "Hundun's Mistake: Satire and Sanity in the Zhuangzi," in Philosophy East and West 67, no. 3 (July 2017), 783-800 < https://muse.jhu.edu/article/664495>.

The Philosophy of the Daodejing (New York: Columbia University Press, 2006).

Moeller, Hans-Georg and Paul J. D'Ambrosio, Genuine Pretending: On the Philosophy of the Zhuangzi (New York: Columbia University Press, 2017).

Møllgaard, Eske, An Introduction to Daoist Thought: Action, Language, and Ethics in Zhuangzi (New York: Routledge, 2007).

Nietzsche, Friedrich, Thus Spoke Zarathustra: A Book for All and None, ed. by Adrian Del Caro and Robert B. Pippin, trans. by Adrian Del Caro (Cambridge: Cambridge University Press, 2006)

Parkes, Graham. "In the Light of Heaven before Sunrise: Zhuangzi and Nietzsche on Transperspectival Experience," in Daoist Encounters with Phenomenology: Thinking Interculturally about Human Existence, ed. by David Chai (London: Bloomsbury Academic, 2020), 61-84.

Sellmann, James D., "Transformational Humor in the Zhuangzi," in Wandering at Ease in the Zhuangzi, ed. by Roger T. Ames (Albany: State University of New York Press, 1998).

Shang, Geling, "Embracing Differences and Many: The Signification of One in Zhuangzi's Utterance of Dao," in Dao: A Journal of Comparative Philosophy, 1, no. 2 (June 2002), 229-250. $<$ http://dx.doi.org/10.1007/BF02857097>.

Shi, Liang, "The Leopardskin of Dao and the Icon of Truth: Natural Birth versus Mimesis in Chinese and Western Literary Theories," in Comparative Literature Studies, 31, no. 2 (1994), 148-164.

Tallis, Raymond, "Zhuangzi and that Bloody Butterfly," Philosophy Now: A Magazine of Ideas (2009), $<$ https://philosophynow.org/issues/76/Zhuangzi_And_That_Bloody _Butterfly>.

Wagner, Rudolf G., A Chinese Reading of the Daodejing: Wang Bi's Commentary on the Laozi with Critical Text and Translation (Albany: State University of New York Press, 2003).

Wang, Youru, Linguistic Strategies in Daoist Zhuangzi and Chan Buddhism: The Other Way of Speaking (London: RoutledgeCurzon, 2003).

Wawrytko, Sandra A., "Deconstructing Deconstruction: Zhuang Zi as Butterfly, Nietzsche as Gadfly," in Philosophy East and West, 58, no. 4 (October 2008), 524-551, < https://doi.org/10.1353/pew.0.0026>

(c) 2021 Anton Heinrich L. Rennesland https://www.kritike.org/journal/issue 28/rennesland1 june2021.pdf

ISSN 1908-7330 


\section{THE AFFIRMATION OF NOTHINGNESS}

Yue, Xiao Dong, "Exploration of Chinese Humor: Historical Review, Empirical Findings, and Critical Reflections," in Humor - International Journal of Humor Research, 23, no. 3 (August 2010), 403-420, $<$ https://doi.org/10.1515/humr.2010.018>.

Zhuang Zi, Zhuangzi: The Complete Writings, ed. by Brook Ziporyn (Indianapolis: Hackett Publishing Company, 2020). Zhuangzi: The Essential Writings, trans. by Brook Ziporyn (Indianapolis: Hackett Publishing Company, 2009).

Žižek, Slavoj, The Parallax View (Cambridge, Massachusetts: MIT Press, 2006). 